\title{
Phenological development of fruits in cultivars of feijoa (Acca sellowiana) and its relationship with South American fruit fly infestation
}

\author{
Hellen Aparecida Arantes dos Santos ${ }^{1}$ (D) Marcia Regina Faita ${ }^{2}$ (D) Afonso Inácio Orth ${ }^{2}$ (D) \\ Luís Gonzaga Ribeiro ${ }^{3}$ João Felippeto ${ }^{3}$ (D) Rubens Onofre Nodari $^{2 *}$ (D)
}

\footnotetext{
${ }^{1}$ Secretaria da Agricultura, Pecuária e Desenvolvimento Rural do Estado do Rio Grande do Sul, Porto Alegre, RS, Brasil.

${ }^{2}$ Programa de Pós-graduação em Recursos Genéticos Vegetais, Centro de Ciências Agrárias, Universidade Federal de Santa Catarina (UFSC), 88034-001, Florianópolis, SC, Brasil. E-mail: rubens.nodari@ufsc.br. “Corresponding author.

${ }^{3}$ Empresa de Pesquisa e Extensão Rural de Santa Catarina.
}

\begin{abstract}
The present study aimed to evaluate the developmental phases of feijoa fruits associated with infestation by Anastrepha fraterculus (Wiedemann) (Diptera: Tephritidae) and the nonpreference of fruit flies for ripe fruits of feijoa. Two tests were carried out. In the first trial, we evaluated the association between the developmental stages of feijoa fruits and infestation by A. fraterculus. To accomplish this, fruits at five different stages of development, from green to ripe, were examined from the Alcântara cultivar. In the second trial, we evaluated the nonpreference of A. fraterculus for ripe fruits of Alcântara, Helena, Mattos and access 2316 cultivars. Physicochemical analyses were performed on the fruits of both trials. In the second test, analyses of polyphenol index and tannin concentration were also performed. Feijoa fruits in stage I are the likely targets of attack by A. fraterculus. The fruits of Alcântara cultivar from stage II, with 39 mm of transversal diameter and soluble solids, presented four puparium / fruit. The fruits of Alcântara and access 2316 cultivars showed greater and lesser infestation, respectively. The fruits of access 2316 also showed a higher concentration of tannins compared to the three commercial cultivars tested, which may have conferred the greatest protection against infestation by A. fraterculus. Feijoa fruits from Alcântara and Mattos cultivars showed high susceptibility to infestation by A. fraterculus, requiring management practices to guarantee commercial production.
\end{abstract}

Key words: Anastrepha fraterculus, goiabeira-serrana, pineapple-guava, resistance of plants, tannin.

Desenvolvimento fenológico de frutos em cultivares de goiabeira-serrana (Acca sellowiana) e sua relação com infestação da mosca-das-frutas Sul Americana

RESUMO: O presente estudo teve como objetivos avaliar as fases de desenvolvimento de frutos de feijoa associadas à infestação por Anastrepha fraterculus (Wiedemann) (Diptera: Tephritidae) e a não preferência por frutos maduros. No primeiro ensaio, foi avaliado a influência dos cinco estágios de desenvolvimento dos frutos de feijoa na infestação por A. fraterculus na cultivar Alcântara. No segundo ensaio, foi avaliado a não preferência de A. fraterculus por frutos maduros das cultivares Alcântara, Helena, Mattos e acesso 2316 . Foram realizadas análises físico-químicas nos frutos de ambos os ensaios. No segundo ensaio, também foram realizadas análises do índice de polifenóis e concentração de taninos. Frutos de feijoa no estágio I são os prováveis alvos de ataque por A fraterculus. Os frutos do cultivar Alcântara, a partir do estádio II, quando apresentavam $39 \mathrm{~mm}$ de diâmetro transversal e sólidos solúveis, apresentaram quatro pupários/fruto. Os frutos da cultivar Alcântara e do acesso 2316 apresentaram maior e menor infestação, respectivamente. Os frutos do acesso 2316 também apresentaram a maior concentração de taninos do que nas três cultivares comerciais testadas, o que pode ter conferido a maior proteção contra infestação por A. fraterculus. Frutos de feijoa das cultivares Alcântara e Mattos apresentaram alta suscetibilidade à infestação por A. fraterculus, o que requer práticas de manejo para garantir a produção comercial.

Palavras-chave: Anastrepha fraterculus, goiabeira-serrana, pineapple-guava, resistência de plantas, tanino.

\section{INTRODUCTION}

Brazil has a large number of neglected or underused native fruit species with the potential for production and fresh consumption, or for processed products, either of which could be a source of income for local small farmers (LEITE \& CORADIN, 2011). In addition, fruits of native species may represent an opportunity for small farmers to gain additional income from niche markets. Feijoa [Acca sellowiana (O. Berg), synonymous Feijoa sellowiana], is considered a potential fruit species for commercial development (DUCROQUET et al., 2000; SÁNCHEZ-MORA et al., 2019).

Feijoa is a species endemic to southern Brazil and Uruguay and appreciated worldwide for the unique taste and aroma of its fruits (SANCHEZMORA et al., 2019). Outside of its center of origin,

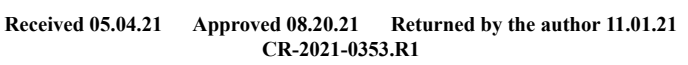


feijoa is produced in several countries, especially Colombia and New Zealand, which are the major producers and exporters of fresh feijoa fruits (PARRA \& FISCHER, 2013; SÁNCHEZ-MORA et al., 2019).

Studies of feijoa over the last two decades have included sensory testing outside of its natural range of occurrence that indicated approval by $90 \%$ of tasters (BARNI et al., 2004), the development of new cultivars (DUCROQUET et al., 2007; 2008), determination of the fruit's physicochemical traits (BORSUK et al., 2017; SÁNCHEZ-MORA et al., 2019) and genetic diversity (DONAZZOLO et al., 2020; SAIFERT et al., 2020), and the identification of nutritional characteristics, as well as antioxidant and antimicrobial activities (WESTON, 2010; AMARANTE et al., 2017; ZHU et al., 2018; PHAN et al., 2019).

Most feijoa cultivation has been carried out by small farmers for their own consumption. However, the amount of fruit marketed in Santa Catarina rose from 86 tons in 2012 to 240 tons in 2018 (CEPA, 2017-2018). Nonetheless, some cultivation issues have arisen. For example, management practices have not kept pace with the growth of crops. Also, the lack of knowledge of sanitary management could limit, in part, large-scale production and the availability of fruits with standards adequate to consumer demand.

Moreover, feijoa fruits are infested by insect pests, such as weevil (Conotrachelus psidii Marshall, 1922) and fruit fly (Anastrepha spp.) (DUCROQUET et al., 2000). The South American fruit fly [Anastrepha fraterculus (Wiedemann, 1830) (Diptera: Tephritidae)] is considered the most adapted species to wild fruit trees (BISOGNIN et al., 2013), determining its predominance as a pest of feijoa (ROSA et al., 2018). Owing to its polyphagous food habit, the pest is highly adaptable to distinct fruit species (KOVALESKI et al., 2000). In addition, its larval development occurs inside the fruits, which causes direct damage and the formation of internal galleries resulting yield losses and commercialization (ZUCOLOTO, 2000). Since the initial development of the larva takes place inside the fruit, no easy, cheap and quick way has been developed to evaluate the extent of damage before harvest. According to the FAO, the losses caused by Tephritidae reach US \$ 1.7 billion each year, and $10 \%$ of these losses occurs in Brazil (FAO, 2013). At the same time, domestic estimative reached US \$ 242 million per year caused by Ceratitis capitata (Diptera: Tephritidae) (OLIVEIRA et al., 2013).

Studies that associate fruit fly infestation with feijoa fruit development stages are scarce, as well as the studies of resistant cultivars. Such studies are essential in developing sanitary management strategies in fruit flies. Thus, the present work aimed to (i) assess the infestation occurrence during distinct stages of feijoa fruit development under field conditions by A. fraterculus and (ii) evaluate the nonpreference of A. fraterculus for ripe fruits of four feijoa genotypes under laboratory-controlled conditions.

\section{MATERIALS AND METHODS}

Sources of adult couples of $A$. fraterculus - For the study carried out in the 2011/2012 growing season, adults were randomized sampled in the $A$. fraterculus population developed from natural collecting and maintained in the Laboratory of Entomology of the Agroveterinary-Center, Universidade Estadual de Santa Catarina (CAV/ UDESC), Lages, SC. In the following growing season (2012/2013), randomized samples of adults were taken from the Laboratory of Entomology, Epagri Experimental Station of São Joaquim (EEESJ). In both Entomology laboratories, the fly populations started with flies collected from infested fruits of nearby fruit orchards. Previously, flies of the referred populations were identified and later on confirmed by a specialist as $A$. fraterculus (NUNES et al., 2015).

Fruit infestation for the present study were done with artificially reared eight-generation adult fruit flies (NUNES et al., 2015), with age between 7 and 18 days. A. fraterculus adults begin the reproductive period on the $7^{\text {th }}$ day (SALLES, 2000). To avoid oviposition of infertile eggs by infertile females, two couples of adult males and females were used in each fruit parcel. Water was supplied ad libitun in cotton pads placed separately in the central part of the cage. Flies were fed with natural solid diet, supplied in a Petri dish, consisted of wheat germ, brown sugar and textured soybean protein in a $1: 1: 3$ ratio. The cages were kept in a breeding room with a temperature of $25 \pm 2{ }^{\circ} \mathrm{C}$ and $\mathrm{RH}$ of $60 \%$.

Two bioassays were carried out with fruits from feijoa cultivars grown in the orchards during the 2011/2012 and 2012/2013 growing seasons:

Bioassay 1 - Effect of developmental stage of feijoa fruits on infestation by Anastrepha fraterculus - This bioassay was carried out at the Experimental Station of Epagri, Lages, Santa Catarina, Brazil (lat. $27^{\circ} 48^{\prime} \mathrm{S}$; long. $50^{\circ} 19^{\prime} \mathrm{W}$; at $884 \mathrm{~m}$ asl). In January of 2012 and 2013, 200 fruits of Alcântara cv (A. sellowiana) approximately 1 $\mathrm{cm}$ in diameter (stage I) were randomly protected with microperforated plastic bags $(12 \times 15 \mathrm{~cm})$ to 
avoid exposure to pests and diseases. During fruit development, characteristics and physicochemical parameters were evaluated weekly to allow the identification of five main stages of fruit development (called stages I, II, III, IV and V), as adapted from the proposed BBCH scale by MEIER (2001) (Table 1). Longitudinal and transversal diameter measurements of the fruits were used as the criteria by which to determine the stages and were carried out with an analogue pachymeter with a resolution of $0.01 \mathrm{~mm}$. Since stage I, 20 fruits with homogeneous development were collected at intervals of seven to ten days, up to ripening stage. Fifteen fruits from each of the five stages were individually packed in plastic cages $(750 \mathrm{~mL})$. The bottom was covered with sterile vermiculite, while the cage was covered with voile fabric and kept in a room $\left(25 \pm 2{ }^{\circ} \mathrm{C}\right.$, RH of $60 \%$, photophase $12 \mathrm{~h}$ ). Two pairs of $A$. fraterculus (14 to 18 days old) were released in each cage and kept in there for $24 \mathrm{~h}$. Before the test setting, the adults of $A$. fraterculus were kept without substrate for oviposition for $48 \mathrm{~h}$. Thirty days after exposure to the flies, the completely rotten fruits were opened, and the vermiculite was sieved to count the pupae and perform the calculations of the fruit infestation index, as determined by the average number of pupae found in each fruit. Each one of the 15 cages was taken as one repetition, and they were randomized.

Physicochemical analyses were performed with five additional fruits collected at each stage in both growing seasons in the Physiology and Postharvest Laboratory of CAV / UDESC. Physical analysis consisted of peeling firmness (expressed in Newton - N), as determined in the equatorial region of the fruits, on two opposite sides, using a digital texturometer. Chemical analyses were performed with the juice obtained from the equatorial cut, followed by hand squeezing onto a steel screen. The soluble solids content (SS) was determined by refractometry, and results were expressed in ${ }^{\circ}$ Brix. Titratable acidity (TA) was determined using $10 \mathrm{~mL}$ of fruit juice diluted in $90 \mathrm{~mL}$ of distilled water. This solution was titrated with $0.1 \mathrm{~N} \mathrm{NaOH}$ to $\mathrm{pH} 8.1$, with the use of an automatic titrator, and the results were expressed as a percentage of citric acid. Fruit juice $\mathrm{pH}$ was determined with a pHmeter (Atago, Japan). The five replications were completely randomized for each physicochemical analysis.

The experimental design consisted of two factors, growing season (years) and fruit stage. Before the Analysis of Variance, pupae count data were transformed to $\sqrt{ }(x+1)$. When a significant $F$ test was obtained, the Tukey test at $5 \%$ probability was used for means comparison.

Bioassay 2 - Evaluation of the nonpreference of $A$. fraterculus for ripe fruits of feijoa cultivars - This bioassay was conducted at Experimental Stations of Epagri of São Joaquim (lat. $28^{\circ} 16^{\prime} \mathrm{S}$; long. $49^{\circ} 55^{\prime} \mathrm{W}$; at $1432 \mathrm{~m}$ asl), Santa Catarina State, Brazil. The free-choice trial was

Table 1 - Stages of fruit development were categorized based on the descriptions of phenological development of fruits presented on the $\mathrm{BBCH}$-scale ("Biologische Bundesanstalt, Bundessortenamt und CHemische Industrie").

\begin{tabular}{|c|c|c|c|}
\hline \multicolumn{2}{|c|}{ Stages of fruit development Feijoa (Acca sellowiana) } & \multicolumn{2}{|c|}{---------Development stages of pomelo fruits $(\mathrm{BBCH})-------$} \\
\hline $\begin{array}{l}\text { Observed developmental } \\
\text { phase }\end{array}$ & Observed description & $\begin{array}{l}\text { Corresponding } \\
\text { phase }\end{array}$ & Description in BBCH-scale \\
\hline I & $\begin{array}{l}\text { Fruits with diameter varying between } \\
22-38 \mathrm{~mm} \text {, firmness of epicarp (33-44 } \\
\mathrm{N}) \text {, and absence of sugars and acidity }\end{array}$ & 74 & Fruit size up to $40 \mathrm{~mm}$ \\
\hline II & $\begin{array}{c}\text { Fruits with diameter equal to, or greater } \\
\text { than, that of ripe fruits; reduction of } \\
\text { firmness }(27-29 \mathrm{~N}) \text {, and presence of } \\
\text { sugars }\end{array}$ & 75 & Fruit with half the final size \\
\hline III & $\begin{array}{l}\text { Fruits with presence of sugars and } \\
\text { acidity and less firmness of the epicarp } \\
\qquad(20 \mathrm{~N})\end{array}$ & 81 & $\begin{array}{l}\text { Beginning of ripening: first appearance of } \\
\text { color }\end{array}$ \\
\hline IV & $\begin{array}{l}\text { Fruits with higher levels of sugar and } \\
\text { acidity; epicarp showing little resistance }\end{array}$ & 85 & $\begin{array}{l}\text { Advanced ripening: increase in the } \\
\text { intensity of specific color of cultivars }\end{array}$ \\
\hline $\mathrm{V}$ & Fruits ready for consumption & 89 & $\begin{array}{l}\text { Ripe fruits for consumption: fruits with } \\
\text { typical flavor and firmness }\end{array}$ \\
\hline
\end{tabular}

Ciência Rural, v.52, n.8, 2022. 
carried out from January to June of 2013. Fruits from Helena, Alcântara, Mattos cultivars and access 2316 were bagged at stage I, as described for Bioassay 1, collected when ripe (stage V), and arranged inside a screened cage $(30 \times 30 \times 30 \mathrm{~cm})$ equidistant from the center. The experimental design used was randomized complete blocks with four replications of eight fruits each. As the ripening does not take place at the same time, ripe fruits $(n=32)$ were harvested in four times, each one then being a block with four replicates of eight fruits. The cages contained a side opening for handling the fruits and introducing the flies, and four pairs of $A$. fraterculus, ages 7 to 18 days, obtained from the Entomology Laboratory of EEESJ were released per cage. During the period of contact with the fruits, the flies received a solid diet of wheat germ, brown sugar and textured soy protein in a $1: 1: 3 \mathrm{v} / \mathrm{v} / \mathrm{v}$ ratio and water in cotton pads placed separately in the central part of the cage. At $48 \mathrm{~h}$ after exposure to the flies, the fruits were removed from the cages, individually placed in plastic pots $(750$ $\mathrm{mL}$ ) with the bottom covered with sterile vermiculite and covered with voile fabric. The fruits were incubated under controlled conditions $\left(25 \pm 2{ }^{\circ} \mathrm{C}\right.$, $\mathrm{RH}$ of $60 \%$, and photophase $12 \mathrm{~h}$ ) for 15 days, after which weekly evaluations started until the complete rotting of the fruits. For each evaluation, the number of pupae present in the vermiculite was counted, and the rate of infestation per gram of fruit and per fruit was calculated. The longitudinal and transversal diameters of the fruit offered for oviposition were measured with a manual caliper, and weight (g) was measured on a semi-analytical scale. The collected data were used to calculate the infestation rate by fruit and by fruit weight.

Similarly, physicochemical analyses were performed in samples of five ripe fruits collected from each of the four genotypes in the Plant Physiology Laboratory of EEESJ. In the physical analyses, two parameters were determined: fruit weight $(\mathrm{g})$, evaluated on a semi-analytical scale, and skin firmness, evaluated with chemical analyses for $\mathrm{SS}$, TA and $\mathrm{pH}$ determined in the same way as that described previously for bioassay I.

Methanolic extracts were obtained from $50 \mathrm{~g}$ of peel pooled from three bagged fruits for each one of the seven feijoa trees (repetitions) and for each genotype. Peels were soaked in $20 \mathrm{ml}$ of methanol (1:1) and kept in a BOD chamber at $30^{\circ} \mathrm{C}$ for $24 \mathrm{~h}$. After this period, partial fractions of the extracts were removed, and another 20 $\mathrm{ml}$ of methanol were added and subjected to $-20{ }^{\circ} \mathrm{C}$ for $24 \mathrm{~h}$. In each partial extract withdrawal, peels were washed with $5 \mathrm{ml}$ methanol (1:1). The total polyphenol index (TPI) was determined by the spectrophotometric method, using Folin-Ciocauteau reagent, as described by SINGLETON \& ROSSI (1965). To quantify the TPI, a calibration curve was constructed using gallic acid at concentrations of 0 to $600 \mathrm{mg} . \mathrm{L}^{-1}$. The coefficient of determination of the analytical curve was $\mathrm{R}^{2}=0.996$. Readings were expressed as gallic acid equivalents per liter $\left(\mathrm{Eag}^{-1}\right)$. To determine the concentration of water-soluble tannin of the epicarp, two samples per treatment were prepared, consisting of $4 \mathrm{ml}$ of diluted solution in distilled water-extract (1:50), $2 \mathrm{ml} \mathrm{H}_{2} \mathrm{O}$, and $6 \mathrm{~mL}$ concentrated $\mathrm{HCl}(12 \mathrm{~N})$. One of the samples was incubated in water bath at $100{ }^{\circ} \mathrm{C}$ for $30 \mathrm{~min}$ (D1), and the other was kept at room temperature (D2). At the end, $1 \mathrm{ml}$ ethyl alcohol (95\%) was added to both samples in order to solubilize the red colored product that had formed. Samples in a quartz cuvette with $10.01 \mathrm{~mm}$ optical path were read with absorbance of wavelength $550 \mathrm{~nm}$ (OD550) in a spectrometer. The difference in optical density was calculated ("D = D1 - D2). Tannin concentration (in milligrams per gram) was calculated as $\mathrm{CT}=19.33 \times$ "D/weight of 50 fruits (RIBÉREAUGAYON \& STONESTREET, 1965). Data were subjected to analysis of variance, and the means were compared by the Tukey test $(\mathrm{P}<0.05)$. The numbers of larvae and pupae were analyzed after being transformed by $\sqrt{ }(\mathrm{x}+1)$.

\section{RESULTS AND DISCUSSION}

\section{Effect of fruit developmental stages on the infestation by Anastrepha fraterculus}

The analysis of variance did not reveal statistically significant interaction between fruit developmental stages and growing seasons $(\mathrm{F}=0,61$, $\mathrm{P}>0,65)$. This result means that the proposed scale in the present study is robust and has the potential to be used in studies of characteristics of fruits and pests and diseases across time. In addition, it was verified that fruit fly infestation started at stage II when fruits measured in average $3.6 \times 3.9 \mathrm{~cm}$ in longitudinal and transversal diameter, respectively. At stage II, the infestation index reached 4.0, when the fruit peel showed a reduction in firmness from 49.94 to $29.95 \mathrm{~N}$ in 2012 and from 33.39 to $27.08 \mathrm{~N}$ in 2013 , comparatively to stage I (Table 2).

During the physiological process of ripening, several metabolic processes are triggered, both synthesis and degradation, which are genetically controlled and lead to senescence (KADER, 1992). In the fruit ripening process, reduction occurs in weight, titratable acidity, and total soluble solids (KLEIN \& THORP, 1987). 
Table 2 - Characterization of feijoa fruits (Acca sellowiana), in different stages of development, offered to fruit flies (Anastrepha fraterculus) during growing seasons 2011/2012 and 2012/2013.

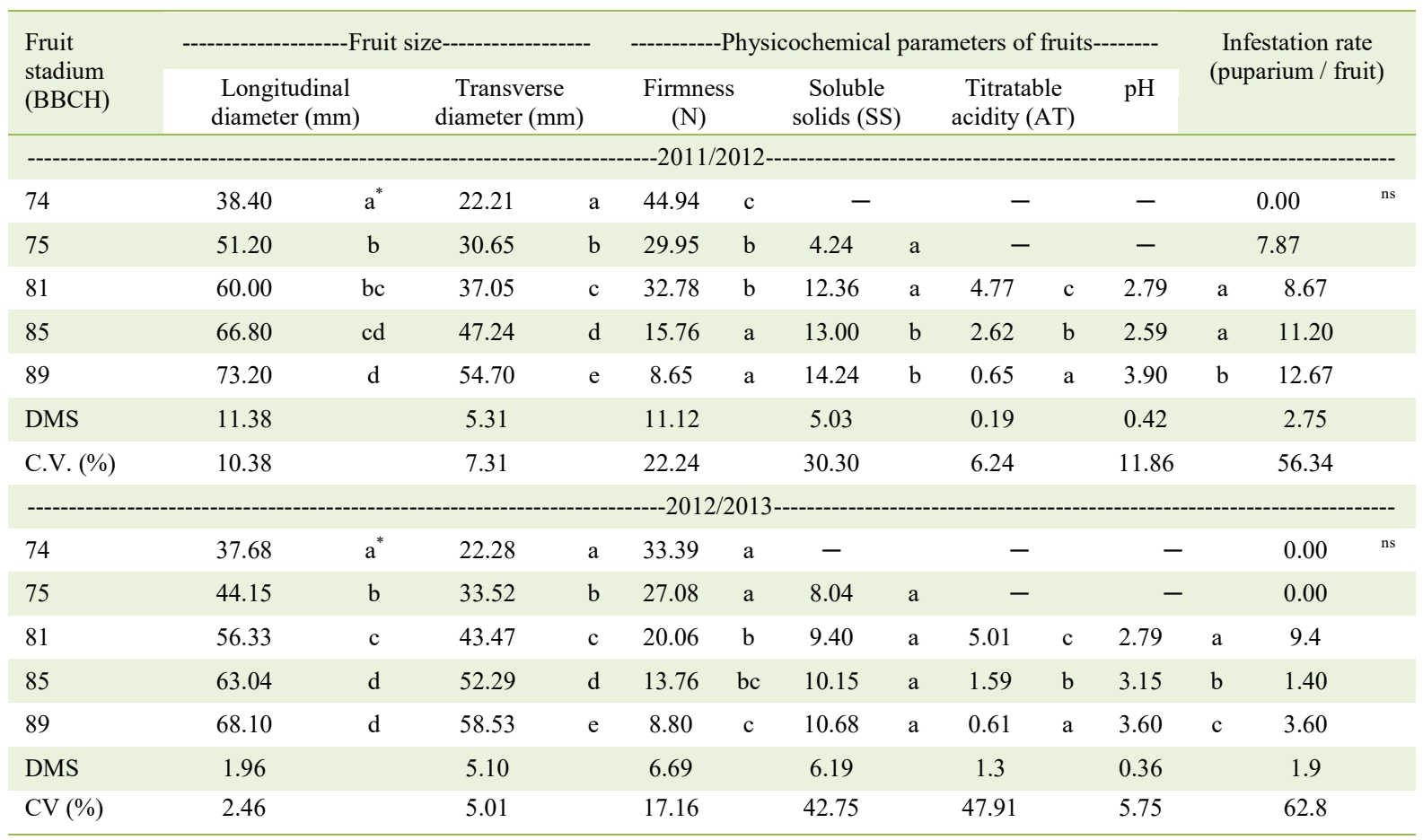

${ }^{*}$ Means in columns within the same growing season followed by same letters do not differ by Tukey test $(\mathrm{P}<0.05) .{ }^{\mathrm{ns}}$ Not significant by the Tukey means comparison test.

The reduction in peel firmness, as well as in soluble solids production, was observed from developmental stage II (Table 2). These results agree with those of GIOVANNONI (2001) since cell wall ultrastructure and texture and the conversion of starch to sugars are the first transformations that occur in fruits during ripening. Afterwards, fruits become more susceptible to pests and diseases (PARRA \& FISCHER, 2013).

During development and physiological ripening of fruits, from stage $\mathrm{I}$ to stage $\mathrm{V}$, peel firmness decreased from 49.94 to $8.65 \mathrm{~N}$ in 2012 and from 33.39 to $8.80 \mathrm{~N}$ in 2013, which agrees with a previous feijoa study carried out in Colombia (RODRÍGUEZ et al., 2006). This change occurs as a result of increased activity of the enzyme polygalacturonase ( $\mathrm{PG}$ ), responsible for the solubilization of pectin present in the pulp and in the fruit epicarp. During fruit ripening, the concentration of PG increases, followed by an increase in its activity, resulting in pectin degradation
(GALVIS, 2003), making the fruit more susceptible to pest attack, as verified in the present study.

Energy reserves and the structural part of plants are constituted by carbohydrates, in particular, sugars, which play an important role in plant development (SOLARTE et al., 2010). According to RODRIGUEZ et al. (2006), fructose and sucrose are the most abundant sugars in the feijoa fruit ripening process. In the present work, it was possible to establish a close relationship between carbohydrates (SS) and fruit fly infestation index. In both crop seasons, early infestation was observed when fruits already presented sugars. Previously, LORSCHEITER et al. (2012) also verified that changes in larval development of $A$. fraterculus were based on high sugar content.

In no-choice bioassay, as observed in the present study, females laid eggs in hosts regardless of conditions favorable to larval development (ZUCOLOTO, 2000). Thus, the present results show 
the importance of adopting preventive measures against the attack of fruit flies in unripe fruits, from stage II onward, in particular the strategy of fruit bagging (TEIXEIRA et al., 2011). Although the results were obtained under laboratory conditions, some caution is justified since oviposition behavior in unripe fruits is not always identical to that which occurs in nature. Results from the field study by DONAZZOLO \& NODARI (2010) revealed statistically significant effect of the use of bags in fruit infestation control against fruit flies. The authors also found that the fruit bagged with non-woven fabric completely prevented the presence of the pest in ripe fruits.

\section{Evaluation of nonpreference of Anastrepha fraterculus for feijoa genotypes}

The analysis of variance among genotypes (three cultivars and one accession) revealed statistical significance for the following ripe fruit characteristics: relative longitudinal/transversal diameters, fruit weight, peel firmness, soluble solids, $\mathrm{pH}$, total polyphenols, tannin concentration, and infestation index per fruit weight (Table 3). However, the same analysis shows no statistical differences for titratable acidity and infestation index per fruit.

The longitudinal/transversal diameter ratio divided the genotypes into two groups: Alcântara and Helena with oblong fruits $(1.34 \mathrm{~mm})$ and Mattos and accession 2316 with round fruits (1.12 and 1.10, respectively). Among the cultivars, it was verified that the Mattos cultivar produced round-shaped fruits with greater weight. Compared with other genotypes, this cultivar also showed the highest content of carbohydrates (soluble solids) and values of $\mathrm{pH}$ and TPI. Analysis of variance showed that the Alcântara cultivar had the highest rate of infestation of flies per kilo of fruit and per individual fruit, although the latter was not significant among genotypes (Table 3).

There was no evidence that AT, SS, fruit shape, peel firmness, and $\mathrm{pH}$ affected the infestation index. The results of the present study disagree with those obtained by RATTANUPUN et al. (2009), once those authors found that the high larval survival of Bactrocera dorsalis Hendel in mango fruits (Mangifera indica L.) resulted from high sugar content and low pericarp resistance.

Comparatively to other cultivars, Alcântara produced smaller fruits (mean weight per fruit of $95.5 \mathrm{~g})$, exhibited the firmest peel and the lowest TPI, and the second lowest tannin concentration. Consequently, among these characteristics, the lowest tannin concentration possibly contributed to the highest fruit fly infestation index, either by fruit, or per fruit weight. Accession 2316 presented fruit characteristics similar to those of the Helena cultivar for weight, peel firmness, $\mathrm{SS}$, and $\mathrm{pH}$, and the means were not statistically different between the two genotypes (Table 3). However, accession 2316 had the highest tannin concentration, 4.3 to 9.1 times higher than the commercial cultivars, although its infestation index was not significantly distinct from that of the Mattos and Helena cultivars. In addition, accession 2316 showed lower infestation index per fruit and per fruit weight than the other tested genotypes, differing significantly from the cultivar Alcântara.

The present study also showed that tannin concentration and phenolic compounds directly influenced infestation. Alcântara cv showed the lowest content of phenolic compounds and the second lowest tannin concentration; at the same time, it presented the highest infestation rates (Table 3). On the other hand, accession 2316 had the lowest infestation rates and the highest tannin concentration. Phenolic compounds are widely distributed in plants, as part of secondary metabolism (TAIZ \& ZEIGER, 2009; HAMINIUK et al., 2012), responsible for pigmentation and protection against ultraviolet light, microorganisms and insects (IGNAT et al., 2011). Factors, such as the degree of fruit ripeness, variety, soil and climate conditions, as well as storage conditions, affect phenolic compounds in fruit (MARTINS et al., 2004). Phenolic compounds may be triggered by the route of ethyl-malate (malonyl-CoA and acetyl-CoA) and by the shikimic acid pathway (carbohydrate) (TAIZ \& ZEIGER, 2009), which also activates the tannins. The chemical defenses of plants against herbivory are partially due to the phenolic compounds that includes tannins. Simultaneously, tannins are responsible for the astringency of many fruits and acts in defense of plants against pests through biological and anti-nutritional properties by forming insoluble complexes with proteins (JEAN-BAIN, 1998). Consequently, insects that feed on plants with high tannin concentration absorb fewer nutrients.

In most studies, tannins are related to the feeding of mammals (OLIVEIRA et al., 2007) since these compounds may not suit the palatability of plants to herbivores, or cause their complete avoidance (RAVEN et al., 2001). However, several studies have shown the effect of tannins on the infestation of different pest species. According to Abraham et al. (2017), in Mangifera indica, fruit fly infestation was inversely proportional to the amount of tannin in the peel of the fruits, in which resistant varieties had higher levels of tannins (13.08 and $13.66 \mathrm{mg} / \mathrm{g}$ ) when 
Table 3 - Relative longitudinal/transversal diameter, weight (g), peel firmness (N), titratable acidity (TA), soluble solids (SS), pH, tannins, total polyphenol index (TPI) and infestation indices (pupae/fruit and pupae/kg of fruit) evaluated in four genotypes of feijoa.

\begin{tabular}{|c|c|c|c|c|c|}
\hline Fruit Traits and Infestation Index & Alcântara & Helena & Mattos & Accession 2316 & C.V. $(\%)$ \\
\hline $\begin{array}{l}\text { Longitudinal/ Transversal diameter } \\
\text { ratio }\end{array}$ & $1.34 \mathrm{~b}^{*}$ & $1.34 \mathrm{~b}$ & $1.12 \mathrm{a}$ & $1.10 \mathrm{a}$ & 10.15 \\
\hline Fruit weight (g) & $95.5 \mathrm{a}$ & $121.2 \mathrm{~b}$ & $149.5 \mathrm{c}$ & $122.8 \mathrm{~b}$ & 25.52 \\
\hline Firmness (N) & $10.6 \mathrm{~b}$ & $6.7 \mathrm{a}$ & $7.7 \mathrm{a}$ & $6.1 \mathrm{a}$ & 34.22 \\
\hline TA & $0.65 \mathrm{~b}$ & $0.55 \mathrm{a}$ & $0.53 \mathrm{a}$ & $0.57 \mathrm{a}$ & 14.37 \\
\hline SS & $10.5 \mathrm{a}$ & $10.3 \mathrm{a}$ & $13.8 \mathrm{~b}$ & $10.6 \mathrm{a}$ & 12.87 \\
\hline $\mathrm{pH}$ & $3.4 \mathrm{a}$ & $3.7 \mathrm{~b}$ & $4.1 \mathrm{c}$ & $3.8 \mathrm{~b}$ & 6.51 \\
\hline Tannins $\left(\mathrm{mg} \mathrm{g}^{-1}\right)$ & $2.03 \mathrm{a}$ & $1.46 \mathrm{a}$ & $2.65 \mathrm{a}$ & $11.50 \mathrm{~b}$ & 27.91 \\
\hline TPI (Eag L $\left.{ }^{-1}\right)$ & $2.44 \mathrm{a}$ & $3.57 \mathrm{~b}$ & $4.10 \mathrm{c}$ & $2.83 \mathrm{a}$ & 12.88 \\
\hline Infestation Index (pupae/fruit) ${ }^{1}$ & $0.66 \mathrm{a}$ & $0.41 \mathrm{a}$ & $0.66 \mathrm{a}$ & $0.38 \mathrm{a}$ & 38.93 \\
\hline Infestation Index (pupae $/ \mathrm{kg})^{2}$ & $8.82 \mathrm{~b}$ & $3.65 \mathrm{a}$ & $3.91 \mathrm{a}$ & $2.61 \mathrm{a}$ & 46.87 \\
\hline
\end{tabular}

${ }^{*}$ Means in columns followed by same letters do not differ by Tukey test $(\mathrm{P}<0.05) .{ }^{1,2}$ Means of primary data.

compared to moderately resistant (10.67 and 11.71 $\mathrm{mg} / \mathrm{g}$ ) and susceptible ( 8.17 to $9.93 \mathrm{mg} / \mathrm{g}$ ) varieties. The concentration of tannins, phenols, alkaloids and flavonoids was higher in resistance, compared to susceptible, varieties of melon (Cucumis melo) to infestation by the fly B. cucurbitae (HALDHAR et al., 2013). The same authors also found that the total content of alkaloids and $\mathrm{pH}$ explained $97.96 \%$ of the total variation of fruit fly infestation, as well as $92.83 \%$ of the total variation in larval density per fruit, based on the presence of alkaloids and total sugar contents. A similar relationship was observed in accession 2316 in the present study since its fruits showed the highest tannin concentration, together with moderate sugar content, as well as the lowest infestation, when compared with the other three genotypes. Taking into account that only pulp is consumed by humans, higher concentrations of tannins in the fruit peel of A. selloviana could be used as markers in plant breeding programs allowing the selection of resistant varieties (HALDHAR et al., 2018; ABRAHAM et al., 2017).

However, it is important to consider that both feijoa peel and pulp produce a highly aromatic volatile oil (WESTON, 2010), as well as bacteriostatic and bactericidal effects against typical foodborne pathogens (SANTOS et al., 2019). This may be one of the factors attracting such pests as the fruit fly since the choice of oviposition sites is apparently related to olfactory stimuli (SALLES, 2000). Additionally, Acca sellowiana is considered the main host of A. fraterculus (ROSA et al., 2018), which is highly abundant in feijoa orchards (ROSA et al., 2017). Thus, efforts towards the discovery and use of bioactive compounds, as well as management practices, to avoid fly infestation of feijoa fruit in commercial orchards would help to avoid fruit damage and economic losses.

\section{CONCLUSION}

Feijoa fruits in stage I are the likely targets of attack by Anastrepha fraterculus, thus requiring some protective measures, such as bagging the fruits before reaching the size for commercial purposes in any agricultural systems, especially those that are organic or agroecological.

Tannin concentration in feijoa was variable among genotypes. However, tannin concentration in accession 2316 was higher than that in the three tested commercial cultivars, which may have conferred the highest protection against infestation by A. fraterculus. The effectiveness of tannins deserves further specific studies.

Feijoa fruits from the Alcântara and Mattos cultivars showed high susceptibility to infestation by 
A. fraterculus, consequently requiring management practices to ensure successful commercial production.

\section{ACKNOWLEDGEMENTS}

The authors would like to thank Empresa de Pesquisa Agropecuária e Extensão Rural de Santa Catarina (EPAGRI) Experimental Stations of Lages and São Joaquim for allowing the use of laboratories and experimental area, for technical support, and for fruit availability; Universidade do Estado de Santa Catarina (UDESC) for allowing the use of the Physiology and Post-harvest Laboratory; Fundação de Amparo à Pesquisa e Inovação de Santa Catarina (FAPESC) for financial support (Repensa Project 5288/2011-4); and Conselho Nacional de Desenvolvimento Científico e Tecnológico (CNPq) for financial support (Repensa Project 479778/2010-8) and the fellowships awarded to RON. We also thank the Coordenação de Aperfeiçoamento de Pessoal de Nível Superior (CAPES) - (Finance code 001) for the scholarships awarded to HAAS and MRF.

\section{AUTHORS' CONTRIBUTIONS}

HAAS, RON and AIO conceived and designed experiments. HAAS, LGR and JF performed field experiments. HAAS carried out the lab analyses. HAAS and MRF performed statistical analyses of experimental data. HAAS, MRF and RON prepared the draft of the manuscript. All authors critically revised the manuscript and approved of the final version.

\section{REFERENCES}

AMARANTE, C.V.T.D. et al. Phenolic content and antioxidant activity of fruit of Brazilian genotypes of feijoa. Pesquisa Agropecuaria Brasileira, v.52, p.1223-1230. 2017. Available from: <https://doi.org/10.1590/s0100-204x2017001200011>. Accessed: Jul. 02, 2018. doi: 10.1590/s0100-204×2017001200011.

BARNI, E.J. et al. Potencial de mercado para goiabeira-serrana catarinense. Florianópolis: Epagri, 2004. 48p. (Documento, 212).

BISOGNIN, M. et al. Biology of South American fruit fly in blueberry, blackberry, strawberry guava, and Surinam cherry crops. Pesquisa Agropecuaria Brasileira, v.48, n.2, p.141147, 2013. Available from: <https://doi.org/10.1590/S0100 204X2013000200003>. Accessed: Jul. 02, 2018. doi: 10.1590/ S0100-204X2013000200003.

BORSUK, L.J. et al. Phenotypic variability in feijoa fruits [Acca sellowiana (O. Berg.) Burret] on Indigenous lands, Quilombolas communities and Protected areas in the south of Brazil. Revista Brasileira de Fruticultura, 39, e-699, 2017. Available from: $<$ https://doi.org/10.1590/0100-29452017699>. Accessed: Jul. 02, 2018. doi: 10.1590/0100-29452017699.

CEPA - Centro de Socioeconomia e Planejamento Agrícola. Fruticultura de Santa Catarina 2017-2018: Área Colhida dos Produtos por Microrregião. Available from: $<$ https://public.tableau.com/profile/cepa4859\#!/vizhome/ FruticulturaSafra2017_2018_Final/PainelMRG?publish=yes>. Accessed: Sep. 23, $201 \overline{9}$.

DONAZZOLO, J.; NODARI, R.O. Efeito do ensacamento sobre a qualidade de frutos de goiabeira serrana. In: SEMINÁRIO:
Sistemas de Produção Agropecuária, 2010, Dois Vizinhos. Anais eletrônicos. Dois Vizinhos: UTFPR, 2010. Available from: $<$ https://web.dv.utfpr.edu.br:448/seer/index.php/SSPA/article/ viewFile/310/183>. Accessed: Jul. 02, 2013.

DONAZZOLO, et al. On farm management of Acca sellowiana (Myrtaceae) as a strategy for conservation of species genetic diversity. Scientia Horticulturae, v.259, p.108826, 2020. Available from: <https://doi.org/10.1016/j.scienta.2019.108826>. Accessed: Jan. 05, 2021. doi: $10.1016 /$ j.scienta.2019.108826.

DUCROQUET, J.P.H.J. et al. Goiabeira-serrana (Feijoa sellowiana). Série Frutas nativas 5. Jaboticabal: Funep, 2000. 66p.

DUCROQUET, J.P.H.J. et al. Novas cultivares brasileiras de goiabeira serrana: SCS 414-Mattos e SCS 415-Nonante. Agropecuária Catarinense, v.21, n.2, p.79-82, 2008. Available from: <https://publicacoes.epagri.sc.gov.br/RAC/article/view/857>. Accessed: Jan. 15, 2020

DUCROQUET, J.P.H.J. et al. As primeiras cultivares brasileiras de goiabeira serrana: SCS 411 Alcântara e SCS Helena. Agropecuária Catarinense, v.20, n.2, p.77-80, 2007. Available from: <https:// publicacoes.epagri.sc.gov.br/RAC/article/view/894>. Accessed: Jan. 15,2020

FAO - Food and Agriculture Organization of the United Nations. FAO-STAT 2013. [Review date: June 2016]. 2013. Available from: $<$ http://www.faostat.fao.org $>$. Accessed: Jan. 15, 2020.

GALVIS, A. Manejo de la cosecha y poscosecha de la feijoa. pp. 111-123. In: Fischer, G., D. et al. Cultivo, poscosecha y exportación de la feijoa (Acca selloviana Berg). Produmedios, Bogotá. 2003. 152 p.

GIOVANNONI, J. Molecular biology of fruit maturation and ripening. Annual Review of Plant Physiology and Plant Molecular Biology, v.52, p.725-749, 2001. Available from: $<$ https://doi.org/10.1146/annurev.arplant.52.1.725>. Accessed: Jan. 15, 2020. doi: 10.1146/annurev.arplant.52.1.725.

HALDHAR, S.M. et al. Allelochemical resistance traits of muskmelon (Cucumis melo) against the fruit fly (Bactrocera cucurbitae) in a hot arid region of India. Phytoparasitica, v.41, n.4, p.473-481, 2013. Available from: <https://doi.org/10.1007/ s12600-013-0325-x>. Accessed: Jan. 15, 2020. doi: 10.1007/ s12600-013-0325-x

HAMINIUK, C.W.I. et al. Phenolic compounds in fruits - an overview. International Journal of Food Science \& Technology, v.47, p.2023-2044. 2012. Available from: <https://doi.org/10.1 111/j.1365-2621.2012.03067.x>. Accessed: Jan. 15, 2020. doi: 10.1111/j.1365-2621.2012.03067.x.

IGNAT, I. et al. A critical review of methods for characterization of polyphenolic compounds in fruits and vegetables. Food Chemistry, v.126, n.4, p.1821-1835, 2011. Available from: $<$ https://doi.org/10.1016/j.foodchem.2010.12.026>. Accessed: Jan. 15, 2020. doi: 10.1016/j.foodchem.2010.12.026.

JEAN-BAIN, C. Aspects nutritionnels et toxicologiques des tanins. Revue de Médecine Vétérinaire, v.149, n.10, p.911-920, 1998. Available from: <https://www.semanticscholar.org/paper/ ASPECTS-NUTRITIONNELS-ET-TOXICOLOGIQUES-DESTANINS-Jean-Blain/4bdf5ed86785d0a369684c42833b628b92c0 00fc $>$. Accessed: Jul. 15, 2020. 
KADER, A.A. Postharvest biology and technology: An overview. In: KADER, A.A. (ed.). Postharvest technology of horticultural crops. Davis, CA: University of California. Division of Agriculture and Natural Resources, 1992. p.15-20. Accessed: Jan. 15, 2020

KLEIN, J. D.; THORP, T. G. Feijoa: post-harvest handling and storage of fruit. New Zealand Journal of Experimental Agriculture, v.15, p.217-221, 1987. Available from: $<$ https://doi. org/10.1080/03015521.1987.10425562>. Accessed: Jan. 18, 2019. doi: $10.1080 / 03015521.1987 .10425562$.

KOVALESKI, A. et al. Rio Grande do Sul. In: MALAVASI, A.; ZUCCHI, R. A. (Ed.). Moscas-das-frutas de importância econômica no Brasil: conhecimento básico e aplicado. Ribeirão Preto: Holos, 2000. p. 285-290.

LEITE, L.L.; CORADIN, L. Introdução. In: CORADIN, L.; et al. Espécies nativas da flora brasileira de valor econômico atual ou potencial. Plantas para o futuro - Região Sul. Brasília: MMA, 2011. 934p.

LORSCHEITER, R. et al. Caracterização de danos causados por Anastrepha fraterculus (Wiedemann) (Diptera, Tephritidae) e desenvolvimento larval em frutos de duas cultivares de quiviseiro (Actinidia spp.). Revista Brasileira de Fruticultura, v.34, n.1, p.67-76, 2012. Available from: <https://doi.org/10.1590/S010029452012000100011>. Accessed: Jan. 18, 2019. doi: 10.1590/ S0100-29452012000100011.

MARTINS, C.R. et al. Atividade polifenoloxidase e compostos fenólicos em pós-colheita de pêssegos cultivado em pomar com cobertura vegetal e cultivo tradicional. Ciencia Rural, v.34, n.3, p.749-754, 2004. Available from: <https://doi.org/10.1590/S010384782004000300015>. Accessed: Jan. 5, 2021. doi: 10.1590/ S0103-84782004000300015.

MEIER, U. Growth stages of mono-and dicotyledonous plants: BBCH Monograph. Federal Biological Research Centre for Agriculture and Forestry. 2 ed. 2001. 158p. doi: 10.5073/20180906-074619.

NUNES, M.Z. et al. Damage and development of Anastrepha fraterculus (Diptera: Tephritidae) in fruits of two pear cultivars. Agrociencia Uruguay, v.19, n.2, p.42-48, 2015. <http:// agrocienciauruguay.uy/ojs/index.php/agrociencia/article/ view/300/255>. Accessed: Jan. 15, 2020.

OLIVEIRA, J.S. et al. Processo fermentativo, digestivo e fatores antinutricionais de nutrientes para ruminantes. Revista Electrónica de Veterinaria, Andalucía, v.8, n.2, p:1-13, 2007. <https://www.redalyc.org/articulo.oa?id=63614239013>. Accessed: Jan. 15, 2020.

PARRA, A.; FISCHER, G. Maduración y comportamiento poscosecha de la feijoa (Acca sellowiana (O. Berg) Burret). Una revisión. Revista Colombiana de Ciencias Hortícolas, v.7, n. 1, p.98-110, 2013. Available from: <http://www.scielo.org.co/pdf/ $\mathrm{rcch} / \mathrm{v} 7 \mathrm{n} 1 / \mathrm{v} 7 \mathrm{n} 1 \mathrm{a} 10 . \mathrm{pdf}>$. Accessed: May. 08, 2020. doi: 10.17584 rcch.2013v7i1.2039.

PHAN, A.D.T. et al. Nutritional characteristics and antimicrobial activity of Australian grown feijoa (Acca sellowiana). Foods. v.8, n.9, p.376, 2019. Available from: <https://doi.org/10.3390/ foods8090376>. Accessed: Jun. 11, 2020. doi: 10.3390/ foods 8090376
RATTANUPUN, W. et al. Bactrocera dorsalis preference for and performance on two mango varieties at three stages of ripeness. Entomologia Experimentalis et Applicata, v.131, p. 243-253, 2009. Available from: <https://doi.org/10.1111 /j.1570-7458.2009.00850.x>. Accessed: Sep. 13, 2020. doi: 10.1111/j.1570-7458.2009.00850.x.

RAVEN, P.H. et al. Biologia Vegetal. 6 ed. Koogan. Rio de Janeiro, Brasil. 2001, 928 p.

RIBÉREAU-GAYON, P.; STONESTREET, E. Le dosage des anthocianes dans le vin rouge. Bulletin de la Societé Chimique de France, v.9, n.419, p. 2649-2652, 1965. Accessed: Jun. 11, 2020.

RODRÍGUEZ, M. et al. Maduración del fruto de feijoa (Acca sellowiana Berg) en los clones 41 (Quimba) y 8-4 a temperatura ambiente en condiciones de la Sabana de Bogotá. Agronomía Colombiana, v.24, n.1, p.68-76, 2006. Available from: <http:// www.scielo.org.co/scielo.php? script $=$ sci_arttext\&pid $=$ S012099652006000100009\&lng=en\&nrm=iso.. Accessed: Oct. 17, 2020.

ROSA, J. M. et al. Fruit fly (Diptera: Tephritidae) assemblage in a feijoa orchard in santa catarina state, Brazil. Revista Colombiana de Entomologia, v. 44, n.1, p.110-115, 2018. Available from: $<$ https://doi.org/10.25100/socolen.v44i1.6547>. Accessed: Mar. 15, 2020. doi: 10.25100/socolen.v44i1.6547

ROSA, J.M. et al. Effect of food lures for monitoring of Anastrepha fraterculus (Diptera: Tephritidae) in Acca sellowiana (Myrtaceae). Revista Colombiana de Entomología, v.43, n.2, p.201-207, 2017. Available from: <https://doi.org/10.25100/socolen.v44i1.6547>. Accessed: Jan. 15, 2020. doi: 10.25100/socolen.v44i1.6547.

SAIFERT, L. et al. Evaluation of the genetic diversity in the feijoa accessions maintained at Santa Catarina, Brazil. Crop Science, v.60, p.345-356, 2020. Available from: <https:// doi.org/10.1002/csc2.20088>. Accessed: Jan. 05, 2021. doi: $10.1002 / \csc 2.20088$.

SALlES, L. A. B. Biologia e ciclo de vida de Anastrepha fraterculus (Wied.). In: MALAVASI, A.; ZUCCHI, R. A. (ed.). Moscas-das-frutas de importância econômica no Brasil: conhecimento básico e aplicado. Ribeirão Preto: Holos, 2000. p. 81-86. Accessed: Oct. 17, 2020.

SÁNCHEZ-MORA, F.D. et al. Characterization of phenotypic diversity of feijoa fruits of germplasm accessions in Brazil. Agrosyst. Geosci. Environ., 2,190005, 2019. Available from: $<$ http://dx.doi.org/10.2134/age2019.01.0005>. Accessed: Oct. 17, 2020. doi: 10.2134/age2019.01.0005.

SANTOS, P.H. et al. Extraction of bioactive compounds from feijoa (Acca sellowiana (O. Berg) Burret) peel by low and highpressure techniques. The Journal of Supercritical Fluids, v.145, p.219-227, 2019. Available from: <https://doi.org/10.1016/j. supflu.2018.12.016>. Accessed: Oct. 17, 2020. doi: 10.1016/j. supflu.2018.12.016.

SINGLETON, V.L.; ROSSI, J.A. Colorimetry of total phenolics with phosphomolybdic-phosphotungstic acid reagentes. American Journal of Enology and Viticulture, v.16, p.144-158, 1965. Accessed: Jan. 05, 2021.

SOLARTE, M.E. et al. Caracterización fisiológica y bioquímica del fruto de guayaba durante la maduración. In: MORALES, A.L.; MELGAREJO, L.M. Desarrollo de produtos funcionales 
promisorios a partir de la guayaba (Psidium guajava $\mathbf{L}$.) para el fortalecimiento de la cadena productiva. Bogotá: Universidad Nacional de Colombia, 2010, p. 85-119. Accessed: Oct. 17, 2020.

TAIZ, L.; ZEIGER, E. Fisiologia vegetal. 4 ed. Porto Alegre: Artmed, 2009. 819p.

TEIXEIRA, R. et al. Efeito do ensacamento dos frutos no controle de pragas e doenças e na qualidade e maturação de maçãs 'Fuji Suprema', Bragantia, v.70, n.3, p.688-695, 2011. Available from: $<$ https://doi.org/10.1590/0100-2945-016/14>. Accessed: Oct. 17, 2020. doi: 10.1590/0100-2945-016/14.

ZHU, F. Chemical and biological properties of feijoa (Acca sellowiana). Trends in Food Science \& Technology, v.81, p.121-131, 2018. Available from: <https://doi.org/10.1016/j. tifs.2018.09.008>. Accessed: Nov. 10, 2020. doi: 10.1016/j. tifs.2018.09.008.

ZUCOLOTO, F.S. Alimentação e nutrição de moscas-das-frutas. In: MALAVASI, A.; ZUCCHI, R.A. (Eds.) Moscas-das-frutas de importância econômica no Brasil: conhecimento básico e aplicado. Ribeirão Preto: Holos, 2000. p.67-80. Accessed: Oct. $17,2020$.

WESTON, R.J. Bioactive products from fruit of the feijoa (Feijoa sellowiana, Myrtaceae): A review. Food Chemistry, v.121, n.4, p.923-926, 2010. Available from: <https://doi.org/10.1016/j. foodchem.2010.01.047>. Accessed: Oct. 17, 2020. doi: 10.1016/j. foodchem.2010.01.047 